\title{
The Transfer of Bilirubin from Blood to Bile in the Neonatal Guinea Pig
}

\author{
Lawrence M. Gartner ${ }^{[34]}$ and Irwin M. Arias \\ Departments of Pediatrics and Medicine, Albert Einstein College of Medicine, New York, N.Y., USA
}

\section{Extract}

The development of hepatic uptake, conjugation, and excretion of bilirubin was investigated in newborn and in adult guinea pigs. Excretion of conjugated bilirubin from liver is rate-limiting in the overall transfer of bilirubin from plasma to bile in newborn as well as in mature guinea pigs. Hepatic excretion of bilirubin gradually matures during the first three weeks of life. Glucuronyl transferase activity was also reduced in liver from newborn guinea pigs less than 72 hours old, but the limitation was apparently insufficient to be rate-limiting in vivo. Cumulative hepatic uptake of bilirubin by the liver was also reduced during the newborn period and achieved adult levels at approximately 15 days of age.

The rate of endogenous bilirubin excretion was the same in newborns of all ages and in adults, suggesting that erythrocyte life span and bilirubin synthesis are similar in newborn and in adult guinea pigs.

\section{Speculation}

Hepatic uptake, conjugation, and excretion of bilirubin are reduced in neonatal guinea pigs that do not manifest physiologic hyperbilirubinemia. Similar studies should be performed in species that have neonatal jaundice. The contribution of impaired hepatic uptake of bilirubin to physiologic jaundice of human infants warrants further study.

\section{Introduction}

The regular occurrence of unconjugated hyperbilirubinemia (physiologic jaundice) in human neonates during the first week of life has stimulated many investigations of bilirubin metabolism in infants and newborn animals of different species $[3,5,6,8,11,14$, $15,16,18,25,28]$. These studies have concerned the hepatic clearance of injected bilirubin from plasma $[18,28]$, the conjugation of bilirubin and other substances with glucuronic acid $[3,5,6,8,11,14,15,16]$, and the excretion of conjugated bilirubin into bile [25].
In each study, the development of only a single aspect of hepatic bilirubin metabolism was investigated. The development of bilirubin uptake by neonatal liver and its possible role in physiologic jaundice have not been examined. In the present study, the development of hepatic uptake, conjugation, and excretion of bilirubin was investigated in the guinea pig. Although physiologic hyperbilirubinemia does not occur in newborn guinea pigs, impaired bilirubin excretion and glucuronide formation have been demonstrated $[3,8,25]$, and the size of these animals permits performance of physiologic studies that are not possible in smaller neonates. 
Methods

Pregnant guinea pigs were obtained from commercial breeding farms and the time of birth of newborns was noted by observation every two hours. Eighty-two newborns of both sexes werc kept with their mothers and permitted to nurse until the time of study. Only male adult animals were used. Newborn animals were selected randomly from 1.5 hours to 31 days of age for various studies and subsequently placed in arbitrarily assigned age groups for analysis (tables I, II and III). Thirty-two newborn and 7 adult animals were infused with unconjugated bilirubin (table I); 22 newborn and 10 adult animals were used for estimation of hepatic glucuronyl transferase activity. in vitro (table II) ; and 27 newborn and 6 adult guinea pigs were used for estimation of plasma and blood volumes necessary for calculation of hepatic uptake of bilirubin (table III). All animals were healthy and vigorous, and experiments during which respiratory distress or death occurred were discarded.

The maximal hepatic excretion of bilirubin $\left(\mathrm{EM}_{\mathrm{CB}}\right)$ was estimated as previously described [1]. Unshaven newborn and adult guinea pigs were anesthetized with $3.0 \mathrm{mg}$ of sodium pentobarbital per $100 \mathrm{~g}$ body weight and polyethylene catheters were placed in an external jugular vein and, following cholecystectomy, in the common bile duct. The abdomen was closed with 000 silk suture and the animals were kept warm using an incandescent light. Physiologic saline was continuously infused into the jugular vein at a rate of $0.070 \mathrm{ml} / 100 \mathrm{~g}$ body weight/min for 30 minutes using a Harvard multi-
Table I. Guinea pigs used in estimation of maximal hepatic bilirubin excretion $\left(\mathrm{EM}_{\mathrm{CB}}\right)$ and cumulative hepatic uptake

\begin{tabular}{cccc}
\hline Age group & $\begin{array}{c}\text { Number } \\
\text { of animals }\end{array}$ & Age range & Mean age \\
\hline $0-24 \mathrm{~h}$ & 9 & $5-24 \mathrm{~h}$ & $15.9 \mathrm{~h}$ \\
$25-48 \mathrm{~h}$ & 4 & $30-36 \mathrm{~h}$ & $33.3 \mathrm{~h}$ \\
$3-5$ days & 3 & $3-5$ days & 3.7 days \\
$6-11$ days & 5 & $7-11$ days & 9.6 days \\
$16-19$ days & 5 & $16-19$ days & 17.2 days \\
$20-31$ days & 6 & $20-31$ days & 24.3 days \\
Adult & 7 & $43-86$ days & 52.3 days \\
\hline
\end{tabular}

Table II. Guinea pigs used to estimate hepatic glucuronyl transferase activity in vitro

\begin{tabular}{lccc}
\hline Age group $^{1}$ & $\begin{array}{c}\text { Number } \\
\text { of animals }\end{array}$ & Age range & Mean age $^{1}$ \\
\hline $0-12$ & 4 & $1.5-10$ & 4.9 \\
$13-24$ & 2 & 20 & 20 \\
$25-48$ & 8 & $28-48$ & 36 \\
$49-72$ & 5 & $57-72$ & 65 \\
$73-120$ & 3 & $81-106$ & 90 \\
Adult & 10 & $60-120$ & \\
\hline
\end{tabular}

I Values are given in hours except for those of adult animals, which are given in days.

Table III. Plasma volume, hematocrit and blood volume of adult and newborn (2-28 days) guinea pigs ${ }^{1}$

\begin{tabular}{lcccc}
\hline $\begin{array}{l}\text { Age } \\
\text { Days }\end{array}$ & $\begin{array}{c}\text { Number of } \\
\text { animals }\end{array}$ & $\begin{array}{c}\text { Plasma volume } \\
\text { ml/100g body weight }\end{array}$ & $\begin{array}{c}\text { HGT } \\
\%\end{array}$ & $\begin{array}{c}\text { Blood volume } \\
\text { ml/100 g body weight }\end{array}$ \\
\hline 2 & 4 & $4.33 \pm 0.06$ & $58.3 \pm 3.4$ & $10.61 \pm 0.94$ \\
3 & 2 & $4.92 \pm 0.34$ & $57.5 \pm 1.5$ & $11.54 \pm 0.74$ \\
4 & 3 & $4.93 \pm 0.26$ & $52.0 \pm 2.1$ & $10.28 \pm 0.06$ \\
7 & 3 & $4.14 \pm 0.28$ & $53.0 \pm 2.1$ & $8.87 \pm 0.87$ \\
11 & 1 & 4.77 & 39.0 & 7.82 \\
12 & 1 & 4.73 & 45.0 & 7.28 \\
13 & 1 & 4.46 & $43.3 \pm 2.0$ & 7.96 \\
17 & 6 & $4.43 \pm 0.19$ & $39.0 \pm 0.6$ & $7.83 \pm 0.28$ \\
21 & 3 & $4.63 \pm 0.16$ & $45.0 \pm 2.5$ & $7.46 \pm 0.56$ \\
$2-28$ & 3 & $4.09 \pm 0.24$ & & 5.31 \\
Adult & 27 & $4.48 \pm 0.08$ & $45.7 \pm 1.3$ & $5.59 \pm 0.20$ \\
\hline
\end{tabular}

1 Values given are mean \pm standard error of mean. 
speed infusion pump. During the following 90 minutes, recrystallized bilirubin in an aqueous solution $(0.43 \%$ $\mathrm{Na}_{2} \mathrm{CO}_{3}$ and $\left.0.45 \% \mathrm{NaCl}\right), 100 \mathrm{mg} / 100 \mathrm{ml}$ at $\mathrm{pH} 7.8$, was similarly infused at $70 \pm 4$ (SE) $\mu \mathrm{g} / 100 \mathrm{~g}$ body weight/min. Bilirubin solutions were kept in the dark. Bile was collected on ice in the dark for eight 15-minute periods, two during saline infusion and six during bilirubin infusion. The volume of bile secreted during each period was determined by weight and the rate of bile flow expressed as $\mathrm{ml} / 100 \mathrm{~g}$ body weight $/ \mathrm{min}$. The concentration of bilirubin was determined in $10-100 \mu \mathrm{l}$ of bile [19] and expressed as $\mathrm{mg} / 100 \mathrm{ml}$. Bilirubin excreted in bile during each of the eight periods was determined from the product of total bilirubin concentration and volume of bile secreted and expressed as $\mu \mathrm{g} / 100 \mathrm{~g}$ body weight/min. Maximal bilirubin excretion was achieved during the third bilirubin infusion period and maintained during the three subsequent infusion periods. The mean of the bilirubin excretion rates obtained in each animal during the three 15-minute periods following attainment of maximal hepatic bilirubin excretion was designated $\mathrm{EM}_{\mathrm{CB}}$, the mean maximal hepatic bilirubin excretory capacity. The corresponding values obtained during the same periods were used for bile flow rate and bile bilirubin concentration.

Endogenous bilirubin excretion $\left(\mathrm{EE}_{\mathrm{CB}}\right)$, the quantity of bilirubin excreted prior to administration of bilirubin, was determined in each of two 15-minute periods during saline infusion. The mean values in each of these periods did not differ significantly, and $\mathrm{EE}_{\mathrm{CB}}$ was expressed as $\mu \mathrm{g} / 100 \mathrm{~g}$ body weight $/ \mathrm{min}$. At the completion of each experiment, blood was obtained by cardiac puncture and the liver removed after perfusion with physiologic saline through the hepatic and portal veins to remove sequestered blood. Total and direct-reacting bilirubin concentrations were determined in $10-100 \mu 1$ of sera [19] and expressed as $\mathrm{mg} / 100 \mathrm{ml}$ of sera. Total and direct-reacting bilirubin concentrations in liver were determined by the method of HARGREAVES [10] and expressed as $\mu \mathrm{g} / \mathrm{g}$ of liver.

The total amount of unconjugated bilirubin entering the liver during bilirubin infusion was estimated from the sum of bilirubin excreted in bile during the bilirubin infusion and total hepatic bilirubin and plasma direct-reacting bilirubin at the end of the bilirubin infusion. Plasma volume was estimated using T-1824 in 33 guinea pigs ranging in age from 3 days to adult life (table III) [20]. This sum, termed cumulative hepatic uptake $\left(\mathrm{CHU}_{\mathrm{B}}\right)$, was expressed as $\mu \mathrm{g} / 100 \mathrm{~g}$ body weight/min of bilirubin infusion. Interpretation of this sum as $\mathrm{CHU}_{\mathrm{B}}$ assumes insignificant extrahepatic synthesis of conjugated bilirubin, absence of increased bilirubin formation in liver during bilirubin infusion, and negligible hepatic bilirubin flux. The calculation probably underestimates $\mathrm{CHU}_{\mathrm{B}}$ by ignoring directreacting bilirubin distributed in tissues other than the liver or excreted in the urine.

Hepatic glucuronyl transferase activity was estimated in liver homogenates from non-infused guinea pigs in vitro using the following procedure (table II). Immediately following decapitation, the liver was removed, placed in $0.154 \mathrm{M} \mathrm{KCl}$ at $4^{\circ}$, blotted, and weighed. A $30 \%$ homogenate of the tissue was prepared in 0.154 $\mathrm{M} \mathrm{KCl}$ using a motor-driven Teflon pestle homogenizer. One $\mathrm{mI}$ of homogenate was added to an incubation medium modified from LATHE and WALKer [15] consisting of $0.3 \mathrm{ml}$ of $0.5 \mathrm{M}$ phosphate buffer, $\mathrm{pH} 7.4$; $0.1 \mathrm{ml}$ of $0.3 \mathrm{M} \mathrm{mg} \mathrm{Cl} ; 1.0 \mathrm{ml}$ of $6.0 \mathrm{mg} / 100 \mathrm{ml} \mathrm{re}-$ crystallized bilirubin in $800 \mathrm{mg} / 100 \mathrm{ml}$ crystalline bovine albumin [31] solution, $\mathrm{pH} 7.6$; and $0.6 \mathrm{ml}$ uridine diphosphate glucuronic acid (UDPGA) [31] at each of four different concentrations $\left(5.5 \times 10^{-3} \mathrm{M}\right.$, $\left.1.1 \times 10^{-2} \mathrm{M}, 2.2 \times 10^{-2} \mathrm{M}, 4.4 \times 10^{-2} \mathrm{M}\right)$. Each assay was also performed in the absence of added UDPGA. Distilled water was added to a total volume of $3.4 \mathrm{ml}$. Incubation proceeded in air in the dark in a Dubnoff metabolic shaker at $37^{\circ}$. Product formation increased linearly between 10 and 30 minutes of incubation, while between 30 and 50 minutes of incubation, product formation was the same. Time of incubation was established at 40 minutes. Over a $\mathrm{pH}$ range of 5.0 to 9.0, optimal activity was observed at $\mathrm{pH} 7.4$. Optimal glucuronyl transferase activity was obtained with homogenates of liver from animals of all ages when $1.1 \times 10^{-2} \mathrm{M}$ UDPGA was used. Product formation increased linearly with addition of 50 to $400 \mathrm{mg}$ wet weight of liver. The tubes were subsequently placed in ice, and $3.0 \mathrm{ml}$ of McIlvaine's buffer [10] (0.96 M citric acid and $0.04 \mathrm{M} \mathrm{Na}_{2} \mathrm{HPO}_{4}, \mathrm{pH} 2.2$ ) was added to each tube. Unincubated controls were used for each homogenate. Total and direct-reacting bilirubin concentrations were determined for each assay tube according to the method of HARGREAVES [10]. Intensity of color formed was determined in a Coleman Jr. spectrophotometer at $525 \mathrm{~m} \mu$. From 30 to $400 \mathrm{mg}$ of recrystallized bilirubin or conjugated bilirubin as fresh rat bile was added separately to $200 \mathrm{mg}$ of homogenized guinea pig liver. Using the method of HARgreaves [10], recovery of added unconjugated bilirubin was 91 to $101 \%$ and recovery of added conjugated bilirubin was 84 to $112 \%$. Glucuronyl transferase activity was expressed as $\mu \mathrm{g}$ of UDPGA-dependent direct-reacting bilirubin formed/g of liver wet weight $/ 40$ minutes after correction for unincubated blank. Results presented are those obtained with optimal UDPGA concentrations $\left(1.1 \times 10^{-2} \mathrm{M}\right)$.

Protein concentration of each homogenate was determined according to Lowry [17] and glucuronyl transferase activity was also expressed as $\mu \mathrm{g}$ of UDPGA-de- 
pendent direct-reacting bilirubin formed/mg of protein/ 40 min.

Diazotized pigments obtained upon completion of the glucuronyl transferase assay were extracted and chromatographed for identification of azo-A and azo-B bile pigment derivatives [26]. Azo pigment $B$ was identified chromatographically, confirming the formation of bilirubin conjugate during incubation of bilirubin with guinea pig liver homogenate and UDPGA.

To further validate the assay of glucuronyl transferase activity, liver obtained from three homozygous adult male Gunn strain rats with glucuronly transferase deficiency and eight normal adult male SpragueDawley rats was similarly studied. Glucuronyl transferase activity estimated in liver homogenates from normal rats at optimal UDPGA concentrations was $111.51 \pm 6.93 \mu \mathrm{g} / \mathrm{g}$ liver $/ 40 \mathrm{~min}$, whereas glucuronyl transferase activity in liver from homozygous Gunn strain rats was only $3.69 \pm 0.91 \mu \mathrm{g} / \mathrm{g}$ liver $/ 40 \mathrm{~min}$.

Results are expressed as the mean value \pm one standard error (SE). The Mann-Whitney $U$ test was used for determination of statistically significant differences between groups at a significance level of $p<0.05$ [9].

\section{Results}

Maximal hepatic bilirubin excretory capacity $\left(\mathrm{EM}_{\mathrm{CB}}\right)$ of adult animals was $14.68 \pm 1.38$ (SE) $\mu \mathrm{g} / 100 \mathrm{~g}$ body weight/min, while the $\mathrm{EM}_{\mathrm{CB}}$ of newborn animals, less than 24 hours old, was $1.01 \pm 0.24 \mu \mathrm{g} / 100 \mathrm{~g} / \mathrm{min}$ a value $7 \%$ of that observed in the adult animals (fig. 1). During the second day of life, $\mathrm{EM}_{\mathrm{CB}}$ increased to $27 \%$ of the adult value and remained constant until the 16th-19th day of age when $\mathrm{EM}_{\mathrm{CB}}$ increased to $65 \%$ of the adult value. By the 20th-31st day of age (mean age 24.3 days), the value for $\mathrm{EM}_{\mathrm{CB}}$ was identical with that of adult animals.

$\mathrm{EM}_{\mathrm{CB}}$ is the calculated product of the concentration of bilirubin in bile and the volume of bile secreted (fig.2). During the first twenty-four hours of life, the mean rate of bile flow was $19 \%$ of that of the adult, $0.0128 \pm 0.0005 \mathrm{ml} / 100 \mathrm{~g}$ body weight $/ \mathrm{min}$. During the following 24 hours, the rate of bile flow increased to $67 \%$ of that of the adult value and was maintained at this level during the following 8 days. By the 16th19 th and 20th-31st day, adult rates of bile flow were achieved. The mean maximal concentration of bilirubin in bile during the first 24 hours of life was $22 \%$ of the adult concentration, $114.9 \pm 7.6 \mathrm{mg} / 100 \mathrm{ml}$ of bile. The increase in concentration of bilirubin in bile with increasing age closely approximated the increase in $\mathrm{EM}_{\mathrm{CB}}$ with age (fig. 1) and remained between 23 and $43 \%$ of adult values for the first 10 days of life. Thus, relative to the adult, the ability to concentrate

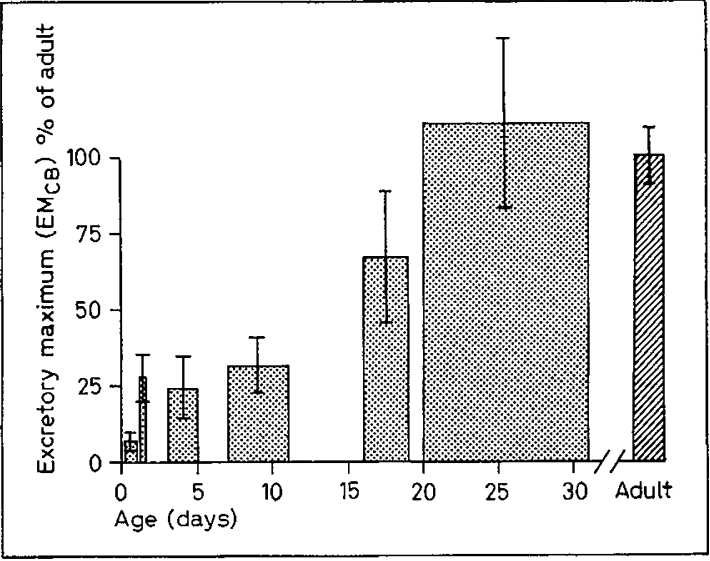

Fig. 1. Maximal hepatic bilirubin excretory capacity $\left(E M_{\mathrm{CB}}\right)$ of newborn and adult guinea pigs expressed as percent of adult value. Adult value $=14.68 \pm 1.38$ (SE) $\mu \mathrm{g} / 100 \mathrm{~g}$ body weight per min. Width of bars represents range of age for each newborn group.

bilirubin in bile is more limited during the first 20 days of life than is the ability to secrete a volume of bile.

Mean cumulative hepatic uptake of bilirubin $\left(\mathrm{CHU}_{\mathrm{B}}\right)$ during the first 24 hours of life was $18 \%$ of that of the adult, $20.56 \pm 1.82 \mu \mathrm{g} / 100 \mathrm{~g}$ body weight/ min (fig. 3). There was a rapid increase in $\mathrm{CHU}_{\mathrm{B}}$ during the next 24 hours, reaching $59 \%$ of the adult rate; during the third to fifth day, $75 \%$ of the adult rate was reached, and by the 16 th-19th day adult rates were achieved. Thus, maturation of $\mathrm{CHU}_{\mathrm{B}}$ occurred earlier than did maximal hepatic bilirubin excretion $\left(\mathrm{EM}_{\mathrm{CB}}\right)$, bile flow, or maximal bilirubin concentration in bile (figs. 1 and 2).

The total bilirubin concentration in normal guinea pig sera was less than $1.0 \mathrm{mg} / 100 \mathrm{ml}$ and in liver was less than $10 \mu \mathrm{g} / \mathrm{g}$ of liver. Following 90 minutes of bilirubin infusion, the mean total serum bilirubin concentration in adult animals was $16.57 \pm 2.64 \mathrm{mg} / 100 \mathrm{ml}$ and the mean direct-reacting serum bilirubin concentration was $3.97 \pm 1.21 \mathrm{mg} / 100 \mathrm{ml}$ (table IV). Total serum bilirubin concentrations in newborn animals of all ages following 90 minutes of bilirubin infusion were similarly elevated, ranging from $11.65 \pm 2.98 \mathrm{mg} / 100$ $\mathrm{ml}$ in the group $0-24$ hours of age to $36.10 \pm 19.70 \mathrm{mg} /$ $100 \mathrm{ml}$ in the group 3-5 days of age (table IV). Concentrations of direct-reacting bilirubin in serum were also elevated, ranging from $2.08 \pm 0.68 \mathrm{mg} / 100 \mathrm{ml}$ in the group 6-11 days of age to $9.10 \pm 3.45 \mathrm{mg} / 100 \mathrm{ml}$ in the group 3-5 days of age (table IV).

Mean hepatic total bilirubin concentration in adult animals following 90 minutes of bilirubin infusion was $142 \pm 26 \mu \mathrm{g} / \mathrm{g}$ liver and that of hepatic direct-reacting bilirubin was $39 \pm 5 \mu \mathrm{g} / \mathrm{g}$ liver (table V). Mean values 


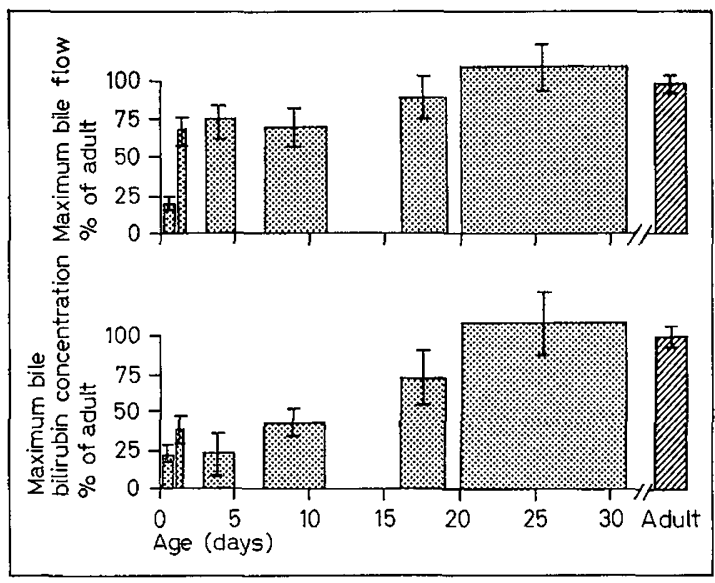

Fig. 2. Bile flow rates and bile bilirubin concentrations of newborn and adult guinea pigs during maximal excretion of bilirubin into bile expressed as percent of adult values. Adult values: bile flow $=0.0128 \pm 0.0005$ (SE) $\mathrm{ml} / 100 \mathrm{~g}$ body weight/min, bile bilirubin concentration $=114.9 \pm 7.6(\mathrm{SE}) \mathrm{mg} / 100 \mathrm{ml}$ bile. Width of bars represents range of age for each newborn group.

Table $I V$. Total and direct-reacting bilirubin concentrations in sera from newborn and adult guinea pigs on completion of bilirubin infusion ${ }^{1}$

\begin{tabular}{cccc}
\hline Age group & $\begin{array}{c}\text { Number } \\
\text { of animals }\end{array}$ & $\begin{array}{c}\text { Total }^{2} \\
\mathrm{mg} / 100 \mathrm{ml} \mathrm{serum}\end{array}$ & $\begin{array}{c}\text { Direct } \\
\text { m }\end{array}$ \\
\hline 0-24 h & 9 & $11.65 \pm 2.98$ & $6.03 \pm 1.84$ \\
$25-48 \mathrm{~h}$ & 4 & $14.07 \pm 6.85$ & $4.50 \pm 1.49$ \\
3-5 days & 3 & $36.10 \pm 19.70$ & $9.10 \pm 3.45$ \\
6-11 days & 5 & $13.70 \pm 6.10$ & $2.08 \pm 0.68$ \\
16-19 days & 5 & $24.28 \pm 5.06$ & $5.36 \pm 0.90$ \\
20-31 days & 6 & $28.93 \pm 3.61$ & $9.05 \pm 1.07$ \\
Adult & 7 & $16.57 \pm 2.64$ & $3.97 \pm 1.21$ \\
\hline
\end{tabular}

1 Values given are mean $t$ standard error of mean. ${ }^{2} \mathrm{p}>0.05$ for each age group comparison.

were significantly lower $(p<0.05)$ in animals less than 24 hours old, than they were in adults. Mean total liver bilirubin concentration in animals less than 24 hours old was $74 \pm 21 \mu \mathrm{g} / \mathrm{g}$ of liver and mean directreacting bilirubin concentration was $10 \pm 2 \mu \mathrm{g} / \mathrm{g}$ liver (table V). Mean total liver bilirubin concentrations in animals from 2 to 31 days old ranged from $110 \pm 10$ to $292 \pm 124 \mu \mathrm{g} / \mathrm{g}$ liver; mean direct-reacting bilirubin concentrations ranged from $11 \pm 4$ to $42 \pm 13 \mu \mathrm{g} / \mathrm{g}$ liver (table V). There was no significant difference $(p>0.05)$ between hepatic bilirubin concentrations in animals more than 24 hours old and in adult animals.

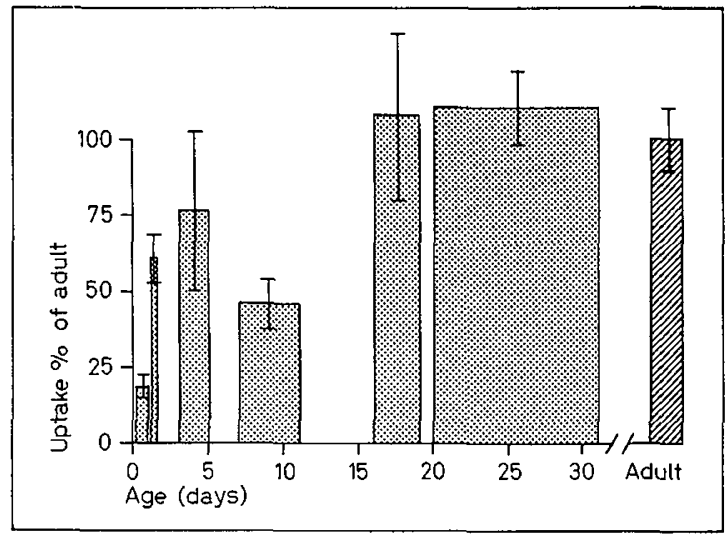

Fig. 3. Cumulative hepatic bilirubin uptake in newborn and adult guinea pigs expressed as percent of adult value. Adult value $=20.56 \pm 1.82(\mathrm{SE}) \mu \mathrm{g} / 100 \mathrm{~g}$ body weight/min. Width of bars represents range of age for each newborn group.

Table $V$. Total and direct-reacting bilirubin concentrations in liver from newborn and adult guinea pigs on completion of bilirubin infusion ${ }^{1}$

\begin{tabular}{|c|c|c|c|}
\hline Age group & $\begin{array}{l}\text { Number } \\
\text { of animals }\end{array}$ & \multicolumn{2}{|c|}{$\mu \mathrm{g} / \mathrm{g}$ liver } \\
\hline $0-24 \mathrm{~h}$ & 9 & $74 \pm 21$ & $10 \pm 2^{3}$ \\
\hline $25-48 \mathrm{~h}$ & 4 & $184 \pm \quad 4$ & $42 \pm 13$ \\
\hline $3-5$ days & 3 & $292 \pm 124$ & $16 \pm 8$ \\
\hline 6-11 days & 5 & $110 \pm 10$ & $11 \pm 4$ \\
\hline $16-19$ days & 5 & $212 \pm 82$ & $42 \pm 8$ \\
\hline 20-31 days & 6 & $120 \pm 23$ & $25 \pm 4$ \\
\hline Adult & 7 & $142 \pm 26$ & $39 \pm 5$ \\
\hline
\end{tabular}

1 Values given are mean \pm standard error of mean.

${ }^{2} \mathrm{p}>0.05$ for each age group comparison except as indicated.

${ }^{3} \mathrm{p}<0.05(0-24$ hours direct versus adult direct) .

Hepatic glucuronyl transferase activity in adult animals was $83.79 \pm 2.87 \mu \mathrm{g}$ of UDPGA-dependent direct-reacting bilirubin formed $/ g$ of liver $/ 40 \mathrm{~min}$ (fig.4). Hepatic glucuronyl transferase activity in animals less than 12 hours old was $20 \%$ of that of adult animals. During the subsequent 36 hours of life, glucuronyl transferase activity gradually increased to $40 \%$ of adult values. Mean glucuronyl transferase activity in the group more than 48 hours old did not differ significantly from that of the adult group. When glucuronyl transferase activity was expressed relative to hepatic protein concentration (fig. 5), the developmen- 


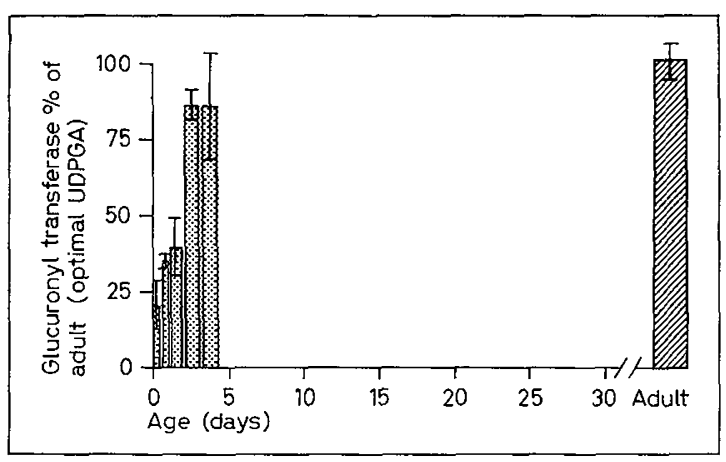

Fig.4. Hepatic glucuronyl transferase activity of newborn and adult guinea pigs at optimal UDPGA concentration expressed as percent of adult value on basis of weight of liver. Adult value $=83.79 \pm 2.87$ (SE) $\mu \mathrm{g} / \mathrm{g}$ liver $/ 40 \mathrm{~min}$. Width of bars represents range of age for each newborn group.

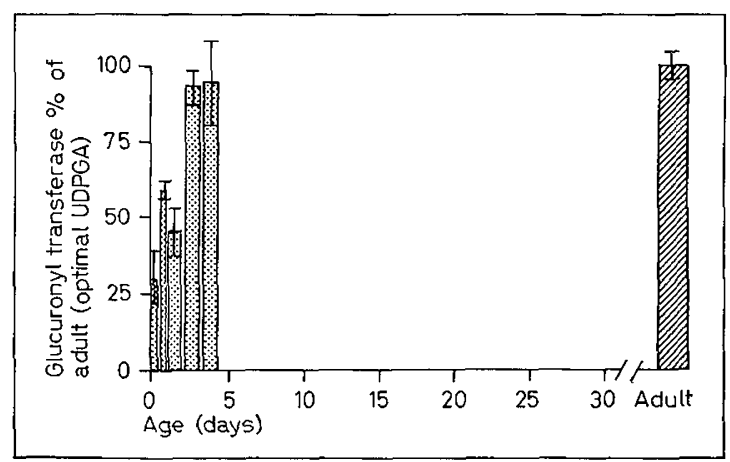

Fig. 5. Hepatic glucuronyl transferase activity of newborn and adult guinea pigs at optimal UDPGA concentration expressed as percent of adult value on basis of protein content of liver. Adult value $=0.529 \pm 0.024$ (SE) $\mu \mathrm{g} / \mathrm{mg}$ protein $/ 40 \mathrm{~min}$. Width of bars represents range of age for each newborn group.

tal curve was not altered and maturation was completed by 48 hours of life. When expressed as a function of body weight (fig. 6), the development of glucuronyl transferase activity was more gradual and activity equivalent to that of adults was achieved between 73 and 120 hours of age. Regardless of the method of expression, however, hepatic glucuronyl transferase activity was mature by the fourth day of life.

Glucuronyl transferase activity in adult liver in vitro, in the absence of added UDPGA, was approximately $50 \%$ of the activity found following the addition of optimal concentrations of UDPGA in vitro (figs. 4 and

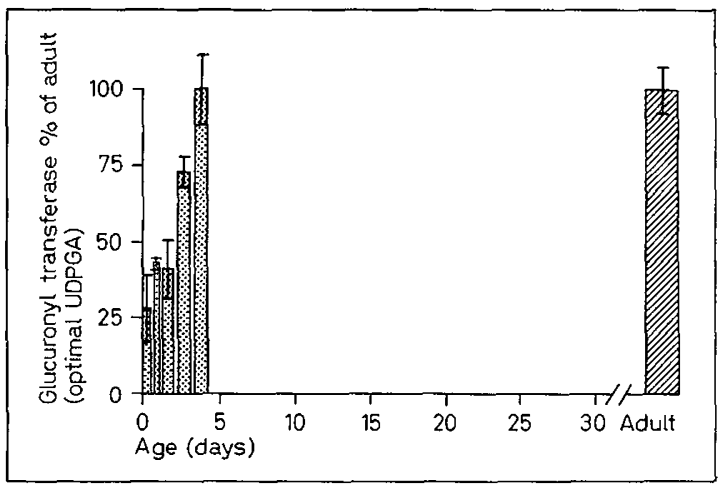

Fig.6. Hepatic glucuronyl transferase activity of newborn and adult guinea pigs at optimal UDPGA concentration expressed as percent of adult value on basis of total body weight. Adult value $=333 \pm 24$ (SE) $\mu \mathrm{g} / 100 \mathrm{~g}$ body weight $/ 40 \mathrm{~min}$. Width of bars represents range of age for each newborn group.

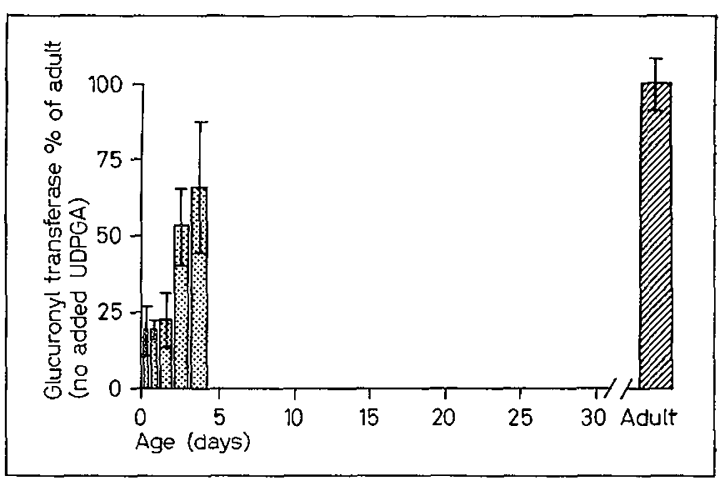

Fig.7. Hepatic glucuronyl transferase activity of newborn and adult guinea pigs without addition of UDPGA expressed as percent of adult value on basis of weight of liver. Adult value $=42.70 \pm 3.23$ (SE) $\mu \mathrm{g} / \mathrm{g}$ liver/40 min. Width of bars represents range in age for each newborn group.

7). Endogenous glucuronyl transferase activity in liver from animals 13 to 120 hours old was approximately $30 \%$ of the activity found following addition of optimal concentrations of UDPGA. In the absence of added UDPGA, glucuronyl transferase activity in vitro on the fourth day of life was $65 \%$ of the activity in livers from adult animals; however, with added UDPGA, adult levels were observed.

The mean protein concentration in liver from animals less than 49 hours old was $104.47 \pm 5.15 \mathrm{mg} / \mathrm{g}$ liver (fig. 8). Between 49 and 72 hours of age, there was a significant increase $(\mathrm{p}<0.05)$ in protein concentra- 


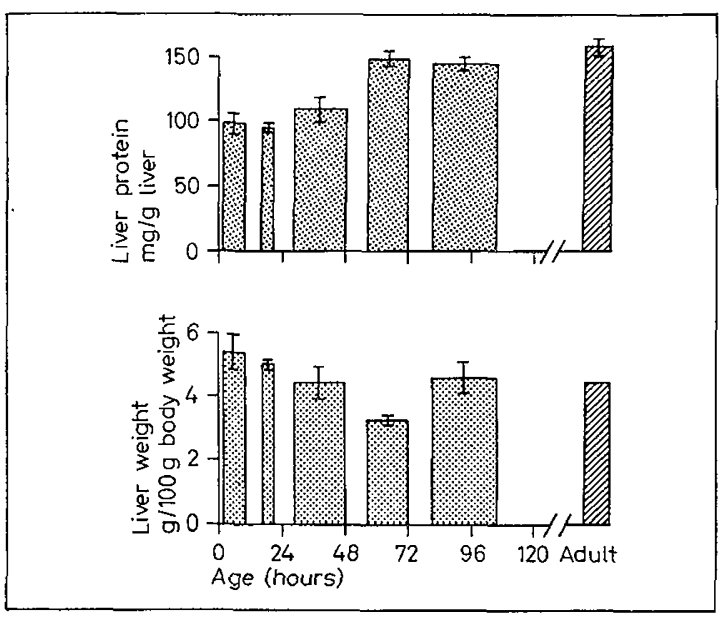

Fig. 8. Protein concentration in liver and relative liver weight of newborn and adult guinea pigs expressed as percent of adult values. Protein concentration is expressed as mg of protein per $g$ of liver. Liver weight is expressed as $\mathrm{g}$ of liver/100 $\mathrm{g}$ body weight. Width of bars represents range of age for each newborn group.

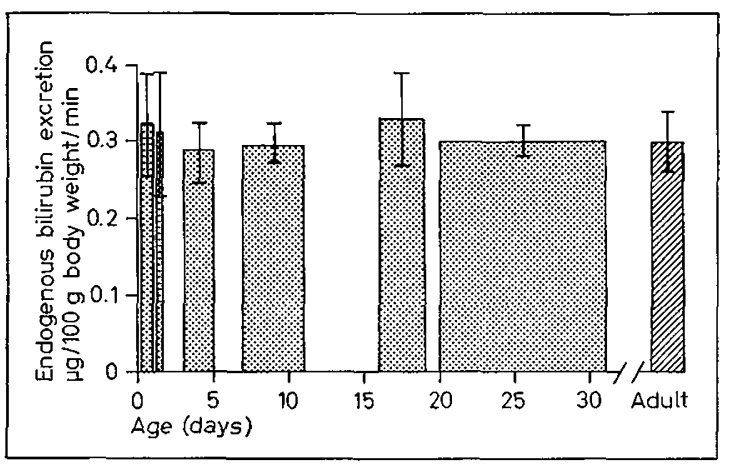

Fig.9. Endogenous bilirubin excretion $\left(\mathrm{EE}_{\mathrm{CB}}\right)$ in bile of newborn and adult guinea pigs expressed as $\mu \mathrm{g} / 100$ $\mathrm{g}$ body weight/min. Width of bars represents range of age for each newborn group.

tion to $148.84 \pm 6.21 \mathrm{mg} / \mathrm{g}$ liver, a concentration similar to that in adult animals. Relative liver weight gradually decreased during the first 72 hours of life from 5.13 $\pm 0.21 \mathrm{~g} / 100 \mathrm{~g}$ body weight during the first 12 hours of life to $3.25 \pm 0.26 \mathrm{~g} / 100 \mathrm{~g}$ body weight by $49-72$ hours of life. However, by 73-120 hours of age, liver weight increased to $5.40 \pm 0.40 \mathrm{~g} / 100 \mathrm{~g}$ body weight, a value identical with that seen in adult animals.

Plasma and blood volumes of newborn and adult animals were estimated in order to compute cumulative hepatic uptake of bilirubin (table III). The mean value for plasma volume of adult animals was $3.03 \pm$
$0.10 \mathrm{ml} / 100 \mathrm{~g}$ body weight, whereas that of animals between 2 and 28 days of age was $4.48 \pm 0.08 \mathrm{ml} / 100 \mathrm{~g}$ body weight, a value significantly greater $(\mathrm{p}<0.05)$ than that of plasma volume of adult animals. Plasma volume remained constant throughout the newborn period, whereas blood volume and hematocrit decreased progressively.

Endogenous bilirubin excretion $\left(\mathrm{EE}_{\mathrm{CB}}\right)$ in newborn animals was $0.32 \pm 0.03 \mu \mathrm{g} / 100 \mathrm{~g}$ body weight $/ \mathrm{min}$ and was unaffected by age (fig.9).

\section{Discussion}

The accumulation of unconjugated bilirubin in plasma may occur as a result of increased bilirubin production, reduced transfer of bilirubin into the hepatic parenchymal cell, and/or impaired conjugation of bilirubin with glucuronic acid. Unconjugated bilirubin must be conjugated and rendered water-soluble to be excreted from the liver cell into bile.

Increased production of bilirubin resulting from exaggerated erythrocyte destruction during the immediate neonatal period has been suggested as a major contributor to physiologic jaundice in normal newborns $[21,22]$. A reduction in erythrocyte life span has been demonstrated in some [22, 29], but not all [4, 13], normal full-term infants. Increased bilirubin production resulting from hemolysis of the magnitude described in normal newborns probably would not produce hyperbilirubinemia unless insufficiency in the hepatic transport or metabolism of bilirubin was also present. In the present study, endogenous bilirubin excretion was the same in guinea pigs of all ages suggesting that bilirubin production is similar in neonates and in adults.

In adult rats [1] and man [24, 27] the excretion of conjugated bilirubin from the liver cell into the bile appears to be rate-limiting in the overall transfer of bilirubin from blood to bile. Previous studies of the biliary excretion of tracer doses of radioactive unconjugated and conjugated bilirubin in newborn and adult guinea pigs suggested that conjugation may be ratelimiting in newborn guinea pigs [25]. In the present study, the hepatic capacity to excrete bilirubin was investigated using bilirubin infusions. It was demonstrated that excretion is rate-limiting in the newborn as well as in the mature guinea pig, even during the first 24 hours of life, at which time bilirubin glucuronide formation is greatly reduced in vitro. The limitation in glucuronyl transferase activity (bilirubin) in the neonate is apparently insufficient to be rate-limiting in vivo. Furthermore, during the first 24 hours of life, conjugated bilirubin accumulated in plasma and in liver, indicating that more conjugated bilirubin was formed than could be excreted by the developing liver. 
Reduction in the capacity of newborn guinea pigs to excrete bilirubin resulted from both decreased volume of bile secreted and the capacity to concentrate bilirubin in bile. Bile flow was markedly decreased only during the first 24 hours of life. The prolonged period of reduction in capacity to concentrate bilirubin in bile suggests that limited transport of bilirubin into bile may be of more significance in the impairment of excretion than is restricted bile flow.

Previous studies of hepatic glucuronyl transferase activity in vitro in guinea pigs utilized o-aminophenol (OAP) and phenolphthalein as glucuronide receptors. Glucuronyl transferase activity was absent in liver microsomes from guinea pig fetal liver and adult rates of activity were not attained until approximately 20 days after birth [3]. Liver homogenates and slices from 72-hour-old animals formed o-aminophenol glucuronide at one-third the rate observed in adult animals [8]. By contrast, in the rat, glucuronyl transferase activity (OAP) was approximately twice as great in homogenates of liver at 11 hours of age when compared with results using homogenates of adult liver. A variety of patterns of development of glucuronyl transferase activity have been observed in newborn animals using various glucuronide receptors as substrates $[5,6,11,14,15]$, suggesting possible multiplicity of glucuronyl transferases. In the present study, bilirubin glucuronide formation by liver obtained from guinea pigs less than 12 hours old was approximately $20 \%$ of that seen in adult liver and adult levels of glucuronyl transferase activity were attained by 48 hours of age. The demonstration of rapid maturation of glucuronyl transferase activity (bilirubin) in vitro is not surprising because the infusion studies indicated that newborn guinea pigs form significant amounts of bilirubin glucuronide in zivo. Attempts to confirm that excretion is rate-limiting were made by the intravenous infusion of conjugated bilirubin. These experiments were unsuccessful because of toxicity occurring during the infusion of either guinea pig or rat bile as the source of conjugated bilirubin.

In the absence of added UDPGA, homogenates of liver from three- and four-day-old guinea pigs demonstrated glucuronyl transferase activity (bilirubin) only $65 \%$ of that of adults, whereas in the presence of optimal concentrations of UDPGA, glucuronyl transferase activity (bilirubin) was comparable to that of adults. This finding suggests that lack of UDPGA during the neonatal period may limit the capacity to form bilirubin glucuronide in vivo and agrees with the previous demonstration [3] that uridine diphosphate glucose dehydrogenase, the enzyme which catalyzes the formation of UDPGA from UDPG, is reduced in the guinea pig during the first week of life. Available UDPGA in neonatal guinea pig liver could also be reduced due to hydrolysis by pyrophosphatase in vitro, as has been demonstrated in neonatal rat liver $[5,8]$. Because glucuronyl transferase (bilirubin) is probably never rate-limiting in the newborn guinea pig, it is impossible from the studies reported here to determine whether lack of availability of UDPGA limits the formation of bilirubin glucuronide in vivo.

Glucuronyl transferase activity is usually expressed on the basis of wet weight of liver $[3,8,14,15]$. Newborn liver, however, may contain more water, lipid, or erythropoietic tissue and expression of enzyme activity on the basis of wet weight could be misleading. In the present study, the development of glucuronyl transferase activity was the same whether expressed relative to liver protein or to wet weight. The rate of maturation of enzyme activity was slightly delayed when activity was expressed relative to body weight. This difference in rate of maturation resulted from changes in liver weight relative to body weight during the first four days of life.

The alterations of liver weight and liver protein suggest that neonatal guinea pig liver loses water, fat, glycogen, or other nonprotein material during the first three days of life, resulting in decreased relative liver weight and increased protein concentration. During the fourth day of life, liver protein concentrations remained constant but relative liver weight increased, suggesting accelerated synthesis of proteins during this period.

The mechanism responsible for transfer of bilirubin from blood into parenchymal liver cells is unknown; therefore, it is not possible to quantitate the kinetics of this process. We have, however, estimated the cumulative hepatic transfer of bilirubin into the liver $\left(\mathrm{CHU}_{\mathrm{B}}\right) \cdot \mathrm{CHU}_{\mathrm{B}}$ represents the minimal mean rate at which unconjugated bilirubin was transferred from plasma into the liver during intravenous infusion of unconjugated bilirubin. By ignoring the amounts of conjugated bilirubin transferred into urine and tissue during the 90 minutes of bilirubin infusion, the actual cumulative uptake of bilirubin may have been underestimated, but only to a small degree, and did not affect the pattern of development. The maturation of $\mathrm{CHU}_{\mathrm{B}}$ was slower than that of conjugation but more rapid than that of excretion.

From 20 to $35 \%$ of infused bilirubin was recovered in bile, liver, and plasma at the conclusion of the experiment. The animals were deeply icteric on completion of the study and extrahepatic, extravascular tissues undoubtedly contained most of the infused unconjugated bilirubin.

The interpretation of data obtained in studies of newborn guinea pigs must be made with caution, since these animals fail to develop physiologic jaundice during the newborn period. The differences between the 
species that develop physiologic hyperbilirubinemia and those that do not may be either qualitative or quantitative. Thus, the guinea pig may have all of the developmental limitations that would be found in the human neonate, but to a less severe degree. It is equally possible that the neonates of those species developing physiologic jaundice have a unique defect. Investigations of the type reported here should be performed in a primate species having physiologic jaundice.

\section{Summary}

The relative rates of development of cumulative hepatic uptake of bilirubin and its subsequent conjugation and excretion were studied in newborn guinea pigs in order to define the rate-limiting step in overall transfer of bilirubin from plasma to bile at different ages of neonatal development. Techniques are described for the determination of hepatic glucuronyl transferase activity in vitro using bilirubin as the glucuronide receptor and for estimation of cumulative hepatic bilirubin uptake in vivo.

Excretion of conjugated bilirubin from the liver cell into bile was rate-limiting in the hepatic transfer of bilirubin from plasma to bile in newborn animals of all ages, as well as in adult animals. Hepatic capacity to form conjugated bilirubin exceeded hepatic capacity to excrete conjugated bilirubin in animals of all ages. Cumulative hepatic bilirubin uptake reached adult capacity after two weeks of age, conjugation of bilirubin after 48 hours of age, and excretion of bilirubin after three weeks of age.

The rate of development of hepatic glucuronyl transferase activity differed according to the glucuronide receptor used. With bilirubin as the glucuronide receptor, glucuronyl transferase activity reached a mature level after 48 hours of age. Previous studies have demonstrated that glucuronyl transferase activity estimated with o-aminophenol as glucuronide receptor in liver from neonatal guinea pigs requires fifteen days to achieve adult levels of activity.

The rate of endogenous bilirubin excretion was the same in newborns of all ages and in adults, a finding which suggests that erythrocyte life span and bilirubin synthesis are similar in newborn and in adult guinea pigs.

The observation that cumulative hepatic uptake of bilirubin was reduced during the newborn period suggests that restricted hepatic uptake of bilirubin could be significant in the pathogenesis of human physiologic jaundice.

\section{References and Notes}

1. Arias, I.M.; Johnson, L. and Wolfson, S.: Biliary excretion of injected conjugated and unconjugated bilirubin by normal and Gunn rats. Amer. J.Physiol. 200: 1091-1094 (1961).

2. ArIas, I. M.; Wolfson, S.; Lucey, J.F. and MCKAY, R.J. Jr.: Transient familial neonatal hyperbilirubinemia. J. clin. Invest. 44: 1442-1450 (1965).

3. Brown, A. K. and Zuelzer, W.W.: Studies on the neonatal development of the glucuronide conjugating system. J.clin. Invest. 37: 332-340 (1948).

4. Dancis, J.; Danoff, S.; Zabriskie, J. and Balis, M.E.: Hemoglobin metabolism in the premature infant. J. Pediat. 54: 748-755 (1959).

5. Durton, G.J.; Langelaan, D. E. and Ross, P.E. : High glucuronide synthesis in newborn liver: choice of species and substrate. Biochem.J. 93: 4-5 (1964).

6. Durtron, G.J. and Lawes, J.: Multiplicity of liver uridine $5^{\prime}$ pyrophosphate glucuronyl transferase from its varying pattern of development with different substrates and species. Biochem.J. 98: 30P (1966).

7. Gartner, L. M.: The hormonal regulation of hepatic bilirubin excretion; in: Bilirubin metabolism (ed. Bouchier, I. A.D. and Billing, B.H.), pp. 175-182 (Blackwell, Oxford 1967).

8. Gartner, L. M. and Arias, I. M.: Developmental pattern of glucuronide formation in rat and guinea pig liver. Amer.J. Physiol. 205: 663-666 (1963).

9. Goldstern, A.: Biostatistics (Macmillan, New York 1964).

10. Hargreaves, T.: The estimation of bilirubin in liver. Clin. chim. Acta 11: 278-280 (1965).

11. Hartiala, K.J.V. and Pulkkinen, M.: Studies on detoxification mechanisms. IV.Glucuronide synthesis in the fetal rabbit. Ann. Med.exp. Fenn. 33: 246 (1955).

12. Hsxa, D.Y.Y.; Dowben, R.M.; Shaw, R. and Grossman, A.: Inhibition of glucuronyl transferase by progestational agents from serum of pregnant women. Nature, Lond. 187: 693-694 (1960).

13. Kaplan, E. and Hsu, K. S.: Determination of erythrocyte survival in newborn infants by means of $\mathrm{Cr}^{51}$ - labelled erythrocytes. Pediatrics 27: 354-361 (1961).

14. Karunairatnam, M.D.; Kerr, L.M.H. and LEVVy, G.A.: Glucuronide-synthesizing system in the mouse and its relationship to B-glucuronidase. Biochem.J. 45: 496-499 (1949).

15. Lathe, G.H. and Walker, M.: The synthesis of bilirubin glucuronide in animal and human liver. Biochem.J. 70: 703-712 (1958). 
16. Lathe, G.H. and WALKeR, M. : Inhibition of bilirubin conjugation in rat liver slices by human pregnancy and neonatal serum and steroids. Quart. J. exp. Physiol. 43: 257-265 (1959).

17. Lowry, O.H.; Rosebrough, N.J.; Farr, A.L. and Randall, R.J.: Protein measurement with the Folin phenol reagent. J. biol. Chem. 193: 265275 (1951).

18. LuCEY, J.F.; BeHRMAN, R. E. and WARshaw, A. L. : 'Physiologic' jaundice in newborn rhesus monkey. Amer.J. Dis. Child. 106: 350 (1963).

19. Malloy, H. and Evelyn, K.: Determination of bilirubin with the photo-electric colorimeter. J. biol. Chem. 119: 481-487 (1937).

20. Mercofr, J. and Favour, C.B.: Determination of blood and plasma volume partitions in the growing rat. Amer.J. Physiol. 141: 695-706 (1944).

21. Mollison, P. L.: Blood transfusion in clinical medicine, 3rd ed., p. 150 (Blackwell, Oxford 1961).

22. Pearson, H.A.: Life-span of the fetal red blood cell. J.Pediat. 70: 166-171 (1967).

23. Roberts, R. J.; KlaAssen, G.D. and PlaA, G.L.: Maximum biliary excretion of bilirubin and sulfobromophthalein during anesthesia-induced alteration of rectal temperature. Proc. Soc. exp. Biol., N.Y. 125: 313-316 (1967).

24. Schalm, L. and Weber, A.Ph.: Jaundice with conjugated bilirubin in hyperhaemolysis. Acta med.scand. 176: 549-553 (1964).

25. Sahenker, S. and Sahmid, R.: Excretion of $\mathrm{C}^{14}$ bilirubin in newborn guinea pigs. Proc. Soc. exp. Biol., N.Y. 115: 446-448 (1964).
26. Schmid, R.: The identification of 'direct-reacting' bilirubin as bilirubin glucuronide. J. biol. Chem. 229: 881-888 (1957).

27. Trsdale, W.A.; Klatskin, G. and Kinsella, E. D.: The significance of the direct-reacting fraction of serum bilirubin in hemolytic jaundice. Amer. J. Med. 26: 214-227 (1959).

28. Vest, M.F.: Physiologie und Pathologie des Neugeborenenikterus. Bibl.paediat., No.69 (Karger, Basel/New York 1959).

29. Vest, M.F. and GRIEDER, H.: Erythrocyte survival in the newborn infant as measured by chromium ${ }^{51}$ and its relation to the postnatal serum bilirubin level. J. Pediat. 59: 194-199 (1961).

30. Zuelzer, W.: In Kernicterus (ed. Sass-Kortsak, A.), p. 39 (University of Toronto Press, Toronto 1961).

31. Sigma Chemical Company, St. Louis, Missouri.

32. This investigation was supported in part by Grant AM 02019 from The National Institute of Arthritis and Metabolic Disease, United States Public Health Service.

33. Dr. Gartner is a Career Development Awardee, National Institute of Child Health and Human Development 1-K3-HD-23073, United States Public Health Service.

34. Requests for reprints should be addressed to: Lawrence M.Gartner, M.D., Department of Pediatrics, Albert Einstein College of Medicine, New York, N.Y. 10461 (USA). 